\title{
Ground subsidence phenomena in the Delta municipality region (Northern Greece): Geotechnical modeling and validation with Persistent Scatterer Interferometry
}

\author{
Federico Raspini ${ }^{\mathrm{a}, *}$, Constantinos Loupasakis ${ }^{\mathrm{b}}$, Dimitrios $\operatorname{Rozos}^{\mathrm{b}}$, \\ Nico Adam ${ }^{\mathrm{c}}$, Sandro Moretti ${ }^{\mathrm{a}}$ \\ a Department of Earth Sciences, University of Firenze, Via La Pira 4, 50121 Firenze, Italy \\ ${ }^{\mathrm{b}}$ Laboratory of Engineering Geology and Hydrogeology, School of Mining and Metallurgical Engineering, National Technical University of Athens, \\ Zographou Campus, GR-157 80 Athens, Greece \\ ${ }^{\mathrm{c}}$ German Aerospace Center (DLR), Remote Sensing Technology Institute, Oberpfaffenhofen, 82234 Weßling, Germany
}

\section{A R T I C L E I N F O}

\section{Article history:}

Received 12 August 2013

Accepted 21 November 2013

\section{Keywords:}

Satellite SAR interferometry

Persistent scatterers

Wide area product

Subsidence modeling

Kalochori

Greece

\begin{abstract}
A B S T R A C T
Land subsidence is a common phenomenon occurring in several regions worldwide. Persistent subsidence causes strong consequences on the affected areas and related problems include environmental, economic and social aspects.

A set of forty-two Synthetic Aperture Radar (SAR) images, acquired in 1995-2001 by the European Space Agency (ESA) satellites ERS1 and ERS2, were processed with Persistent Scatterer Interferometry (PSI) technique to investigate spatial and temporal patterns of deformation in the Delta municipality (Thessaloniki plain, Northern Greece), a deltaic area with a long history of land subsidence related to aquifer system compaction.

Exploitation of output products of a PSI analysis, both average LOS (Line of Sight) deformation rates and displacement time series, revealed a large subsidence area due to intense groundwater withdrawal. Higher displacement velocities have been observed south-west of Kalochori and south of Sindos, from both sides of the Gallikos River. In those areas deformation rates of roughly $4.5 \mathrm{~cm} / \mathrm{yr}$ have been recorded, during the period from 1995 to 2001.

Increasing subsidence rates are measured moving toward the mouth of the Gallikos River, where the thickest sequence of compressible Quaternary sediments is observed. Displacement time series retrieved by PSI technique has been compared with the temporal evolution of the deformation as measured by pre-existing leveling surveys, showing a great agreement.

A 2-D finite element model has been run along two representative cross sections in the Kalochori area, in order to simulate the observed temporal evolution of subsidence, coupling the geotechnical behavior of the formations and the piezometric surface level. Finally, results obtained by the subsidence model have been positively compared with the PSI-based information on displacement, providing accurate and perfectly verified results.

Outcomes of this work demonstrated the potential of repeat-pass satellite SAR interferometry (InSAR) as suitable technique for increasing knowledge about the extent and the rate of the deformations in case of subsidence events. Moreover, InSAR turned out to be a valuable tool to validate subsidence models and represents a cost-efficiency method, alternative to ground-based measurements for investigating surface deformation phenomena.
\end{abstract}

(C) 2013 Published by Elsevier B.V.
* Corresponding author at: Department of Earth Sciences, University of Firenze, Largo Enrico Fermi, 2 Arcetri, 50125 Firenze, Italy. Tel.: +39 0552057782.

E-mail addresses: federico.raspini@unifi.it, raspini.federico@gmail.com (F. Raspini), cloupasakis@metal.ntua.gr (C. Loupasakis),rozos@metal.ntua.gr (D. Rozos), Nico.Adam@dlr.de (N. Adam), sandro.moretti@unifi.it (S. Moretti).

\section{Introduction}

Land subsidence induced by the overexploitation of aquifers is a very common natural hazard striking extensive areas worldwide and in many cases urbanized areas, causing remarkable economic cost annually. The Gioia Tuaro plain (Raspini et al., 2012) and Bologna (Stramondo et al., 2007) in Italy, the Anthemountas basin (Raspini et al., 2013) and the Thessaly plain in Greece (Kontogianni 
et al., 2007; Rozos et al., 2010), Murcia in Spain (Tomás et al., 2005), Mexico city (Osmanoglu et al., 2011) and Morelia (Cigna et al., 2012a) in Mexico, Tokio in Japan (Hayashia et al., 2009), Las Vegas (Amelung et al., 1999) and the Antelope valley (Galloway et al., 1998) in USA, Taiwan (Hung et al., 2010), Jakarta in Indonesia (Ng et al., 2012) and large zones in China (Xue et al., 2005; Zhang et al., 2011) are few examples of areas where subsidence caused by over-pumping has been identified and monitored. Review of occurrence, detection, measurement and mechanical models of the expected ground subsidence induced by aquifers exploitation are presented by Gambolati et al. (2005) and Galloway and Burbey (2011).

Despite the numerous bibliographic sources describing the land subsidence mechanism, the geotechnical simulation of the phenomenon is often a challenging task. The poly-parametric subsidence mechanism (involving geological, geotechnical, hydrogeological and many other components) and the overlapping of different sources of deformation (natural and human-related) make subsidence investigations complicated and require the intervention of multiple scientific specialties.

The territory of the Delta municipality, in the eastern sector of the Thessaloniki plain, is not an exception to the rule, as the study and even more the simulation of land subsidence phenomena in this area encountered several difficulties. The complexity of subsidence caused confusion among researchers leading to the proposition of a great variety of interpretations for the explanation of the phenomenon (Andronopoulos et al., 1990, 1991; Dimopoulos, 2005; Hatzinakos et al., 1990; Loupasakis and Rozos, 2009; Psimoulis et al., 2007; Rozos and Hatzinakos, 1993; Stiros, 2001). At the Kalochori village, the most affected area of Delta municipality, subsidence phenomenon took place for several decades, without being noticed at the beginning. This fact makes impossible retrieving detailed information of the total vertical displacements and, as a consequence, the conduction of back analysis for the calibration of the geotechnical simulation of the phenomenon.

The main objective of the current work, focusing on the land subsidence occurring in the Delta municipality, is twofold: to assess the contribution of the remote sensing data on the study of the phenomenon and to identify the main causes of the observed ground deformations.

The achievement of the first objective benefits of the recently retrieved Persistent Scatterer Interferometry (PSI) data (produced in the framework of the European Space Agency Terrafirma Extension project), which provide accurate historical information on range and rate of the subsidence, for a period of 6 years (1995-2001).

The second objective can be achieved thanks to the development of integrated methodology combining conventional in situ investigations and geotechnical modeling, run to simulate the land subsidence. The numerous studies conducted for the entire region provided plenty of data, covering all the requirements for setting up a finite element simulation model of the water pumping-induced subsidence phenomenon.

Finally, the availability of PSI data allowed the verification of the reliability and robustness of the results obtained with simulation.

\section{Delta municipality: description of the study area}

Located on the northern part of Thermaikos Gulf, the municipality of Delta covers an area of about $300 \mathrm{~km}^{2}$, with more than 40000 inhabitants. The municipality was formed in 2011 after the local government reform, by merging three former municipalities (Axios, Chalastra and Echedoros).
Thanks to its strategic position close to the Thessaloniki seaport, a natural gateway toward the Balkan Peninsula, this area experienced a rapid economic growth, becoming, during the 1960s, a flourishing industrial center in the region, accommodating the major part of industrial activity of the Thessaloniki plain. Many of those industries are heavy industries (i.e., skin processing, fabric industries and chemical industries), some others deal with animals slaughtering and food processing. All of these activities are high demanding from the water supply point of view. The villages of Kalochori and Sindos host the two main industrial areas of the municipality, developed straddling the Gallikos River, on its east and west side, respectively.

\subsection{Geological and hydrogeological setting}

The urbanized areas of Delta municipality have developed by occupying the easternmost sector of the Thessaloniki coastal plain, a delta formed in the last 2500 years. The plain is the largest deltaic area of Greece, with an extension of more than $1500 \mathrm{~km}^{2}$. The landscape in the central part of the Plain is smooth, slightly dipping toward the sea, while close to the coastline it is flat.

The urban fabric of the Delta municipality, located at an elevation of few meters above sea level, developed above loose Quaternary deposits. These deposits, unconsolidated to partly consolidated marine-lacustrine sediments, filling a NW-SE oriented tectonic graben, consist mainly of sand and black silty clays (Hatzinakos et al., 1990; Rozos et al., 2004). The Neogene basement, buried by a $300-400 \mathrm{~m}$ thick sequence of Quaternary deposits, is represented by sandstones and red clays and outcrops in the north and in the north-east border of the area of interest (Fig. 1).

Thanks to the availability of several deep geotechnical boreholes drilled in the Kalochori region, Andronopoulos et al. (1991) classified the Quaternary formations in three horizons (sandy, silty and black silty clay). Rozos et al. (2004) reconstructed the architecture of the upper lithostratigraphic units, consisting of an uppermost sandy horizon lying over a silty clay layer and a deeper pattern alternating coarse and fine sediments.

With regard to the hydrogeological conditions, the abovedescribed stratigraphic pattern led to the development of an unconfined shallow aquifer in the uppermost sandy horizon and of a system of deeper confined-artesian aquifers below the silty clay layer, characterized by very low hydraulic conductivity. Despite the presence of about 300 wells exploiting the shallower aquifer within the limit of Kalochori and Sindos village (Soulios, 1999), the level of the uppermost aquifer has not been affected by lowering, due the limited exploitation forced by the quite low quality of the water. Most of the wells are low-consumption and the extracted water is mainly used by the farmers for irrigation purposes or occasionally as drinking water for livestock.

On the contrary, since the early 1960s many deep water wells, exploiting the deep confined aquifers, have been drilled by the water company of Thessaloniki, to provide drinkable water to the city, and by the private companies to satisfy the flourishing industrial area. At the early 1950s, before the beginning of exploitation, the piezometric surface of this aquifer was above ground level and most of the wells were artesian. Continuous discharge and excessive consumption for about three decades caused a considerable lowering of the confined ground water table, which fell to a maximum depth of almost $40 \mathrm{~m}$ from the surface (Andronopoulos et al., 1990).

Because of the excessive problems caused by the land subsidence at the mid 1980s the water company decided to stop pumping water allowing the partial recovery (5-15 $\mathrm{m}$ ) of the piezometric surface. Therefore, at the end of 1990s the piezometric level varied from 25 to $35 \mathrm{~m}$ below ground level (Soulios, 1999). According to measurements conducted between 1997 and 2001, the level 


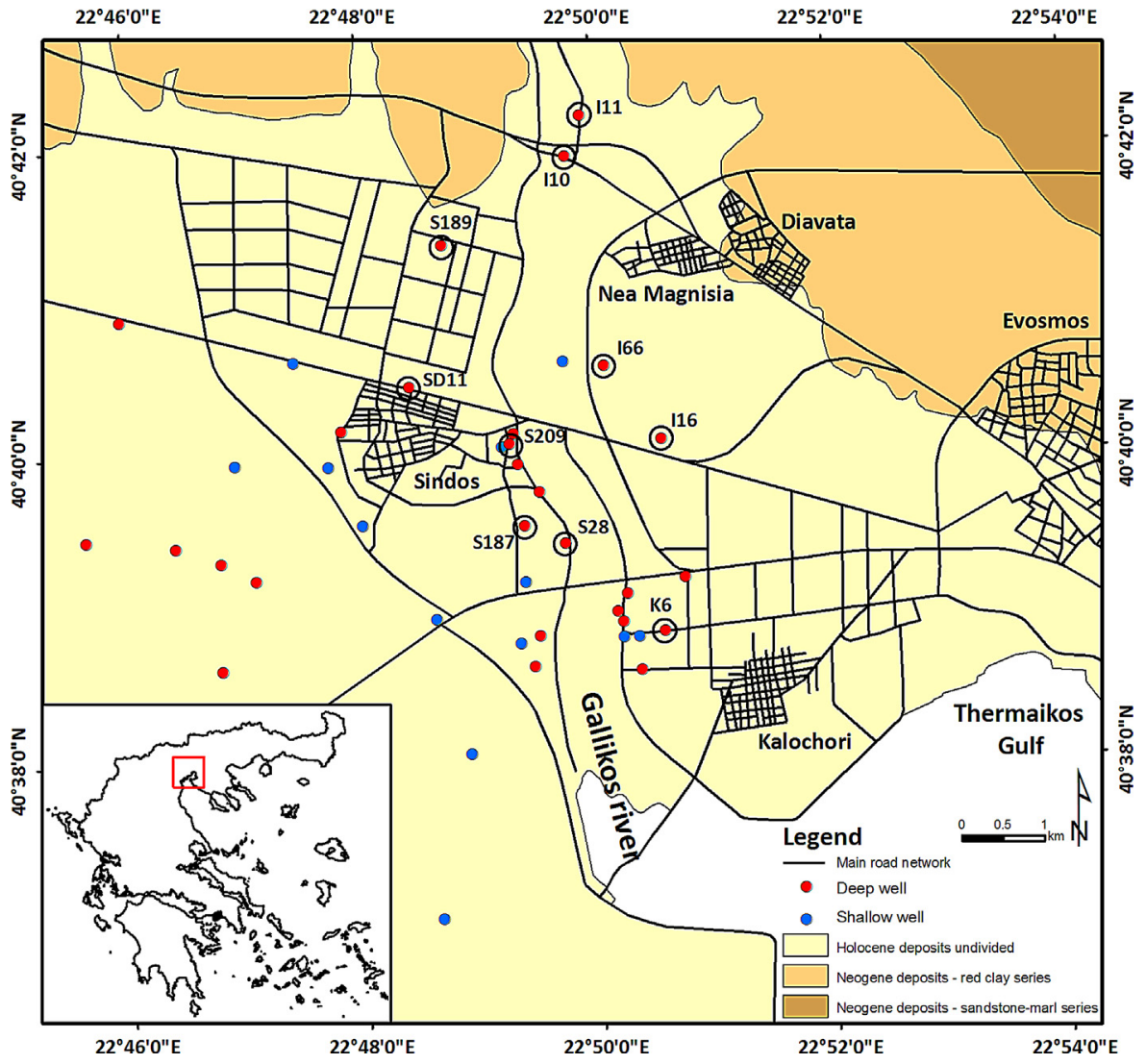

Fig. 1. Geology of the study area redrawn from IGME (1978), plus water wells location. Circles indicate location of well of Fig. 2.

of the piezometric surface in the Sindos-Kalochori region varied from 25 to $40 \mathrm{~m}$ (Fig. 2). Despite the lack of continuity in the available records, the piezometric data show that groundwater either remains almost constant or presents a slight lowering due to the occasional increasing water consumption from the private wells.

As additional information regarding the ground water piezometry it worth mentioning that during a field survey carried out in July 2012, it was observed that the level of the piezometric surface in the Sindos-Kalochori region has unexpectedly recovered, varying from +1 to $-8 \mathrm{~m}$. It seems that several high-consumption industrial wells stop operating during the last years. The fact that numerous industries of the Kalochori industrial area shut down because of the financial crises justifies this assumption. The net reduction in ground-water extraction, the progressive abandonment of highconsumption water wells and last but not least, the economic crisis which forced many industries to close, led to an almost complete recovery of the aquifer.

\subsection{Land subsidence: historical background}

The Sindos-Kalochori wide area is a perfect example of how subsidence phenomena can be subtle and difficult to detect. Despite the groundwater exploitation started at the early 1960 to foster the industrial development of the area, subsidence was firstly noticed only in 1965 , as a progressive marine transgression. In 1969, during a period of intensive rainfall, strong wind and barometric peak, the seawater inundation reached the southernmost part of the Kalochori village. This situation forced the Department of the Ministry of Public Works to build a $3 \mathrm{~km}$-long embankment along the entire coastline. This embankment has been subjected to several damages and reconstructions as it collapsed in 1973 and in 1979. Finally, in 1980 a bigger embankment was constructed, proved able to resist to the deformations of the subsidence phenomena. The construction of this new embankment allowed as well the reclamation of several $\mathrm{km}^{2}$ of land, trapping, on the other hand, streams form flowing to the sea. Over time a shallow lagoon developed, an artificial surface drainage network was arranged and several pumping stations were installed, aiming to protect the inland areas from flooding during wet season. Nowadays, after decades of loss of elevation, the entire coastal zone is susceptible to be inundated and the integrity of the embankment is vital to protect the village. Its fundamental importance is highlighted in Fig. 3. As presented, the sea level is about $0.5-1.0 \mathrm{~m}$ below the level of the road built on the top of the embankment (Fig. 3c) and the lagoon water level, in the inland area, is at least $4 \mathrm{~m}$ below the road level (Fig. $3 \mathrm{~b}$ ).

Over a period of several decades, different scientists have detected and reported few more indicators of the occurring subsidence. Beside the pipe protrusions observed in many wells (Fig. 3d), the submerged electricity network (Fig. 3e) installed along the side of a road constructed SW of Kalochori in 1975, is perhaps the most impressive evidences of land subsidence. As the deformations threatening the Kalochori village became more evident, the subsidence draw the attention of many researchers, which investigated this area of Greece both at basin and local scale, with different approaches and exploiting several techniques. Many studies are currently available, providing data on ground deformation affecting the Thessaloniki region. Some of the above-mentioned studies employed conventional ground-based instruments, such as leveling benchmarks, GSP station and triangulation (Doukas et al., 2004; Psimoulis et al., 2007; Stiros, 2001); some others exploited the contribution of InSAR (Interferometric Synthetic Aperture Radar) approach, both classical differential (Mouratidis et al., 2009) and multi-interferometric approach (Raucoules et al., 2008).

Despite the extensive sets of geological, geotechnical and geodetic data supplied by these investigations, a general agreement on the generation mechanism of the phenomenon is missing. 


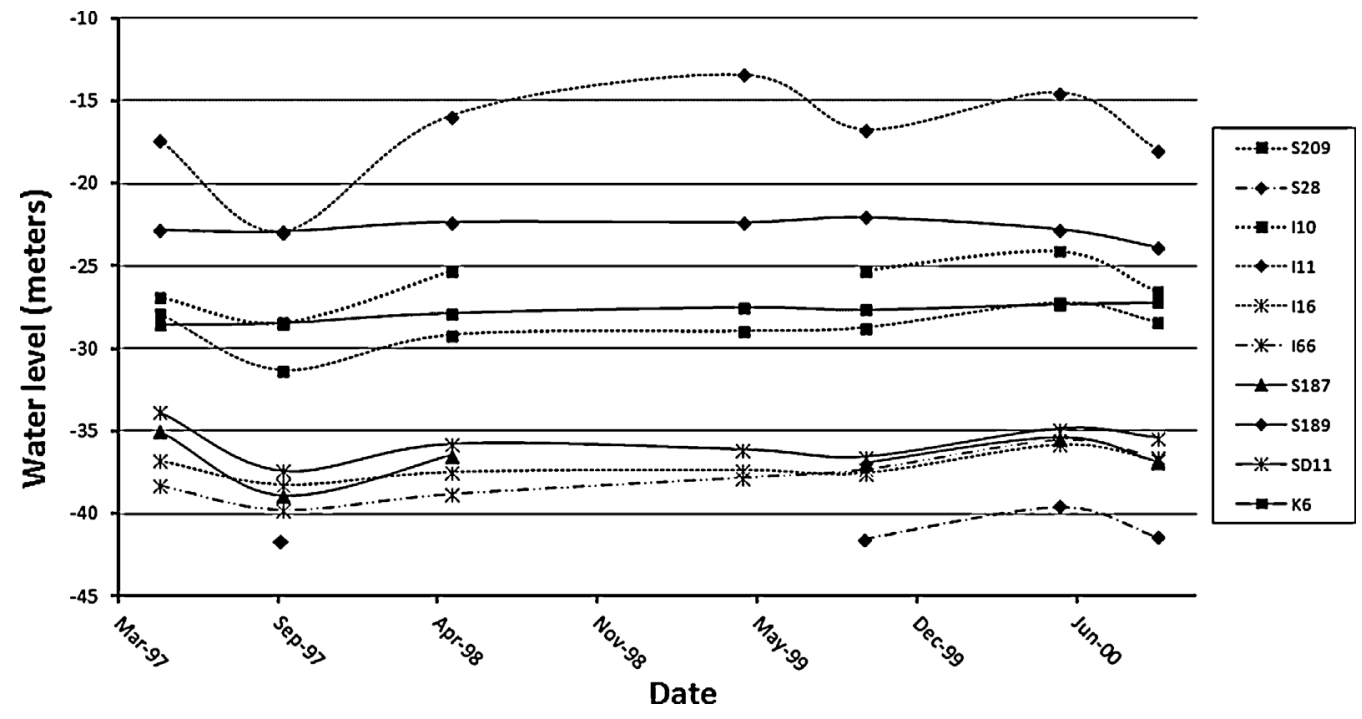

Fig. 2. Piezometric level variation (1997-2001) for water wells indicated in Fig. 1.

Although the majority of the investigation (Andronopoulos et al., 1991; Hatzinakos et al., 1990; Loupasakis and Rozos, 2009; Rozos and Hatzinakos, 1993) states that the overexploitation of aquifers is the main cause of subsidence, some authors have suggested alternative factors that have possibly contributed to the subsidence phenomena.

According to Stiros (2001), in addition to reservoir compaction due to the decline of the piezometric level, other supplementary causes of the ground subsidence are: (i) the consolidation of near-surface sediments; (ii) the oxidation of peat soils in the vadose zone following the abandonment of the delta and the deviation of the Axios flow in 1945; (iii) the synsedimentary

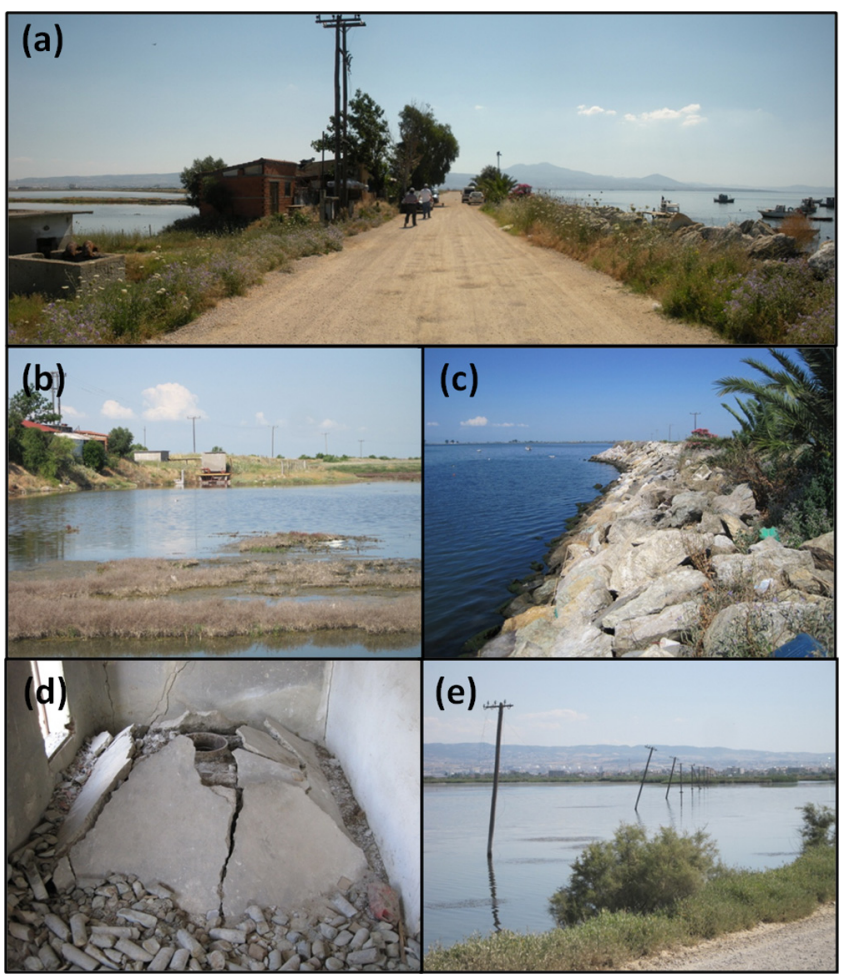

Fig. 3. Field evidences of subsidence: (a) top view of the embankment; (b) inland view: a pumping station is also presented; (c) seaside view; (d) pipe's upheaval in a deep well west of Kalochori; and (e) submerged electricity network SW of Kalochori. deformation of the delta (faulting and flow); (iv) loading-induced consolidation of deeper sediments. In addition, coastal erosion and sea-level rise caused by climate changes (Doukakis, 2005), consolidation of the loose silty-clay deposits and flowing sand phenomenon taking place close to the coastline (Dimopoulos, 2005), long-term, natural plain-wide delta deformation with superimposed local effects such as over-pumping (Psimoulis et al., 2007), have been reported as potential causes of the recorded ground subsidence.

It worth highlight that among the possible causes of the observed subsidence any relative (i.e., regional) or absolute sealevel rise can be discarded. The amplitude of most of these events (few $\mathrm{mm} / \mathrm{yr}$ ), due to eustatic or tectonic effects, is at least one order of magnitude lower than that recorded subsidence (few $\mathrm{cm} / \mathrm{yr}$ ).

\section{Methodology}

Besides the impact on landscape, subsidence-related problems include many aspects: environmental, economic and social. Examples of successful efforts to mitigate specific subsidence problems exist and they include regulation of systems of groundwater pumping, alternative water supply and critical areas mapping. Adopted policies and solutions for land subsidence management can be varies, but despite this variability, mitigation of subsidence requires actions in coordinated steps. As recognized by the US National Research Council (1991), in cases where mitigation methods have to be put into practice, detailed mapping, characterization and simulation of subsidence have to precede their design and implementation.

Hence, besides the application of satellite interferometry to the industrial area of Sindos-Kalochori to assess ground deformation phenomena, the aim of this study is to develop and validate, for the area of Kalochori, a methodology combining:

(i) conventional in situ investigations (water level measurements, stratigraphic and geotechnical data, land use information, distribution of human activities and evidences of deformation);

(ii) geotechnical modeling, run to examine the land subsidence by means of a finite element simulation analysis;

(iii) space measurement of past displacement derived from PSI analyses, used to check and validate the ground deformations as calculated by the modeling activities. 
Besides the unambiguous identification of the causal factors of the occurring subsidence, this validated approach may represent a tool to predict potential ground subsidence as response to various pumping scenarios and to evaluate the effectiveness of mitigation measurements eventually adopted in subsidence-affected areas.

\section{Analysis of subsidence with PSI: results and interpretation}

Phase information of SAR images obtained by instruments onboard satellites can be exploited through differential SAR interferometry (DInSAR), a method designed to retrieve ground displacement occurred between the two different acquisitions of the same target area (Gabriel et al., 1989; Massonnet and Feigl, 1998). Once the topography contribution has been modeled and removed, the phase-difference image (called interferogram) maps and quantifies, along the Line of Sight (LOS) of the satellite, possible ground deformations that may have occurred between the first and the second acquisition.

The application of conventional DInSAR is limited by different constraints, named temporal and geometrical decorrelation phenomena (Zebker and Villasenor, 1992) and by phase distortions introduced by atmospheric effects (Massonnet and Feigl, 1995). To overcome these limitations, InSAR-based information can be enhanced through the PSI technique, a recently developed technology based on analysis of long stacks of co-registered SAR imagery.

Following the PSInSAR (Permanent Scatterer InSAR) approach (Ferretti et al., 2000, 2001), the first algorithm specifically implemented to process long series of SAR images, many multiinterferometric techniques were developed (Werner et al., 2003a,b for Interferometric Point Target Analysis; Berardino et al., 2002 and Lanari et al., 2004 for Small-BAseline Subset; Arnaud et al., 2003 and Duro et al., 2005 for Stable Point Network; Mora et al., 2003 for Coherent Pixels Technique; Hooper et al., 2004, 2007 for the Stanford Method for Persistent Scatterers; van der Kooij et al., 2006 for Coherent Target Monitoring; Kampes and Usai, 1999; Ketelaar, 2009 for Delft Persistent Scatterer Interferometry; Costantini et al., 2008 for Persistent Scatterers Pairs). Regardless of the methods, classical PSI algorithms focus on ground resolution elements containing a single dominant scatterer having stable radiometric characteristics (PS, Permanent Scatterers). Exploiting phase information backscattered from point-like radar targets, PSI proved to be very effective in urbanized area, partially failing over natural terrain due to the low density of the PS network. More recently, the SqueeSAR (Ferretti et al., 2011) and the quasi-PS technique (Luo et al., 2012) were proposed to enhance the performances of PSI approach, through the detection of both distributed and partially coherent targets. The development of these new methods contributed to extend the ability of PSI to natural terrain, partially overcoming the main limitation of the technique (Raspini, 2013).

In recent years, thanks to the capabilities of these advanced approaches to retrieve slow surface deformations (up to several $\mathrm{cm} / \mathrm{yr}$ ), geoscientists have exploited SAR-based information to resolve the spatial distribution and temporal evolution of displacements in many applications. PSI has been developed into an operational and commercially rewarding remote sensing technology. Primarily, analyses performed exploiting PSI information concern areas affected by slow or very slow moving landslides (e.g., Bianchini et al., 2012; Bovenga et al., 2012; Cigna et al., 2012b; Colesanti et al., 2003; Colesanti and Wasowski, 2006; Farina et al., 2006; Herrera et al., 2013; Liu et al., 2013; Tofani et al., 2013) or by land subsidence (e.g., Chaussard et al., 2013; Cigna et al., 2012a; Dixon et al., 2006; Herrera et al., 2009; Osmanoglu et al., 2011). Besides that, examples exist of application for tectonic motions (e.g., Bürgmann et al., 2006; Cakir et al., 2003; Cigna et al., 2011;
Table 1

ERS1 and ERS2 SAR images used for WAP processing.

\begin{tabular}{|c|c|c|}
\hline Date & Perpendicular baseline (m) & Temporal baseline (days) \\
\hline 10-APR-1995 & -174.8 & -631 \\
\hline 15-MAY-1995 & -558.6 & -596 \\
\hline 19-JUN-1995 & -274.3 & -561 \\
\hline 20-JUN-1995 & -418.3 & -559 \\
\hline 25-JUL-1995 & 139.1 & -524 \\
\hline 2-ОСТ-1995 & 370.8 & -455 \\
\hline 3-ОСТ-1995 & 805.0 & -454 \\
\hline 25-MAR-1996 & -820.6 & -281 \\
\hline 26-MAR-1996 & -904.0 & -280 \\
\hline 29-APR-1996 & 766.2 & -245 \\
\hline 4-JUN-1996 & -624.4 & -209 \\
\hline 9-JUL-1996 & 368.5 & -174 \\
\hline 17-SEP-1996 & -36.1 & -104 \\
\hline 22-ОСТ-1996 & 671.1 & -69 \\
\hline 26-NOV-1996 & 983.6 & -34 \\
\hline 31-DEC-1996 & 0 & 0 \\
\hline 11-MAR-1997 & 79.7 & 70 \\
\hline 15-APR-1997 & 621.8 & 105 \\
\hline 20-MAY-1997 & -58.0 & 140 \\
\hline 24-JUN-1997 & -85.9 & 175 \\
\hline 29-JUL-1997 & 16.4 & 210 \\
\hline 2-SEP-1997 & 400.5 & 245 \\
\hline 7-ОСТ-1997 & 413.1 & 280 \\
\hline 16-DEC-1997 & -281.3 & 349 \\
\hline 5-MAY-1998 & 438.1 & 490 \\
\hline 14-JUL-1998 & -587.2 & 559 \\
\hline 28-AUG-1998 & -359.3 & 595 \\
\hline 1-DEC-1998 & -199.6 & 699 \\
\hline 16-MAR-1999 & 66.1 & 805 \\
\hline 29-JUN-2999 & 290.1 & 910 \\
\hline 2-AUG-1999 & 188.7 & 943 \\
\hline 3-AUG-1999 & -67.1 & 944 \\
\hline 7-SEP-1999 & -513.8 & 979 \\
\hline 12-ОСТ-1999 & -435.5 & 1014 \\
\hline 16-NOV-1999 & 35.1 & 1050 \\
\hline 21-DEC-1999 & -181.8 & 1085 \\
\hline 13-JUN-2000 & -218.9 & 1260 \\
\hline 22-AUG-2000 & 374.9 & 1330 \\
\hline 26-SEP-2000 & 388.8 & 1365 \\
\hline 31-ОCT-2000 & 91.0 & 1400 \\
\hline 5-DEC-2000 & 223.4 & 1435 \\
\hline 9-JAN-2001 & -38.1 & 1470 \\
\hline
\end{tabular}

Musson et al., 2004) or volcanic activity (e.g., Amelung et al., 2000; Brunori et al., 2013; Lanari et al., 2004).

For the analysis of subsidence in the Delta municipality, a set of 42 SAR imagery in C-band ( $5.6 \mathrm{~cm}$ wavelength; frequency $5.3 \mathrm{GHz}$ ), acquired between April 10, 1995 and January 9, 2001 (Table 1), has been employed to reconstruct the temporal and spatial patterns of land subsidence. Imagery, taken along descending orbits in Stripmap mode by ERS1/2 satellites, have been processed through the Wide Area Product (WAP) approach (Adam et al., 2011), implemented by DLR (German Aerospace Center).

WAP, whose main objective is to map land deformation at country-level, is a recent algorithmic developments funded by ESA and allows the processing of rural and even mountainous areas (Adam et al., 2011). Many challenges are solved by this development, e.g., the rare availability of PSs and the spatially varying PS density as well as a low PS quality with respect to their phase stability. Practically, global error propagation needs to be avoided with affordable computational cost. This is the reason; all algorithms in DLR's PSI processing system have been assessed and adapted accordingly. Besides, many new algorithms have been developed (Adam et al., 2013). Exemplarily, the WAP processing includes the mitigation of troposphere effects by inclusion of a Numeric Weather Model (NWP). An overview of the WAP results for ERS1/2 datasets is shown in Fig. 4, as measured by the SAR sensor along the satellite's LOS. The color scale indicates green points as 


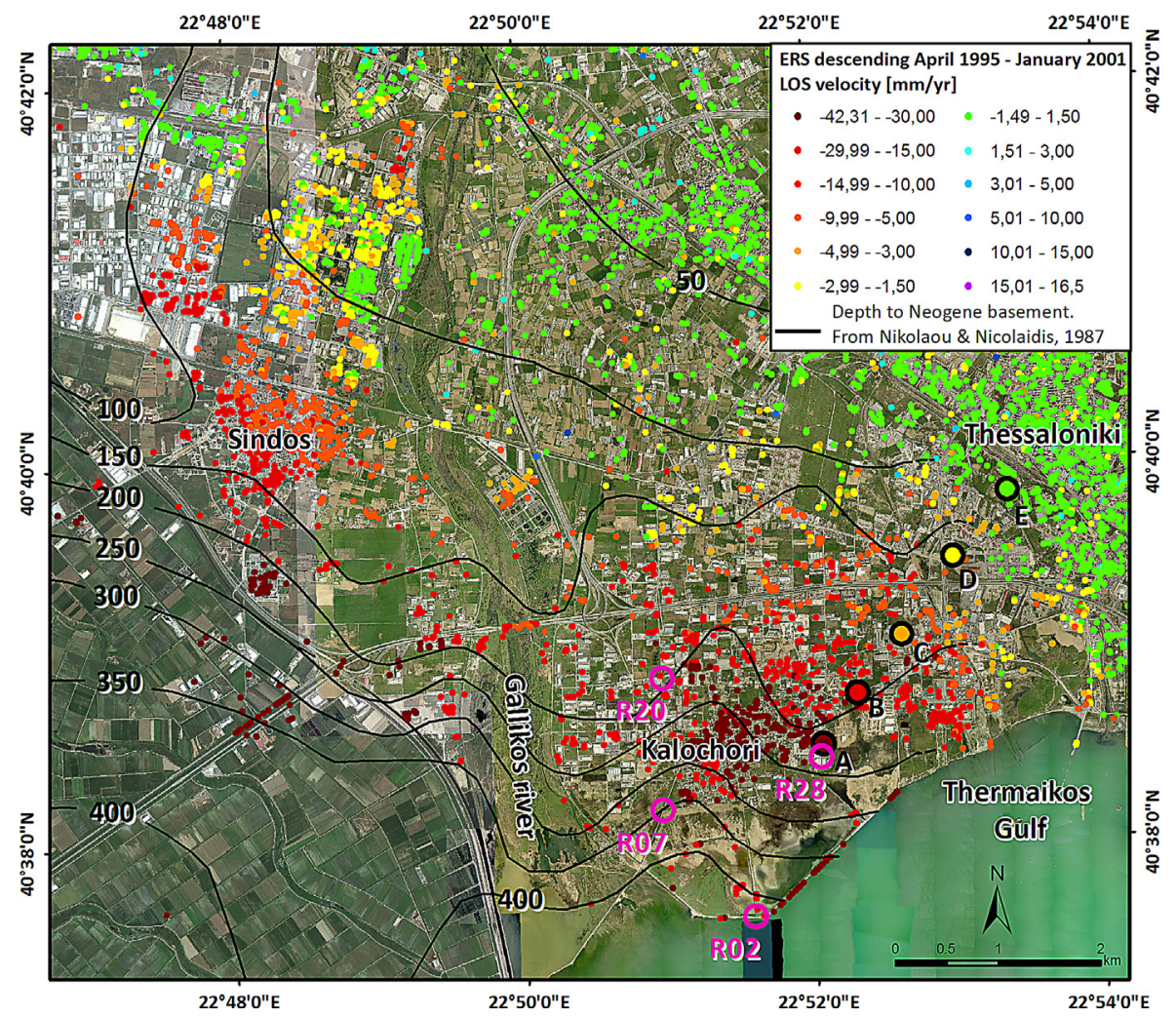

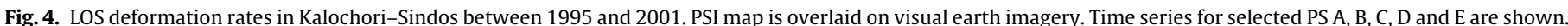

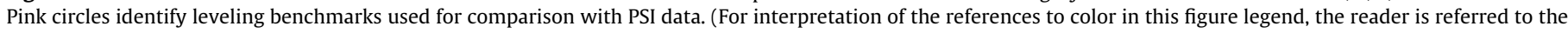
web version of the article.)

stable. The gradation from yellow to dark red represents increasing deformation rates, moving away from the sensor.

As in all multi-interferometry applications, output results of the WAP analysis are relative both in time and in space. Deformation data are calculated in time with respect to the master image (December 31, 1996), and referred in space with respect to a reference point, chosen in area unaffected by surface motion (Thessaloniki downtown).

Analysis of the velocities map shows that the city of Thessaloniki and its closest conurbation, being built over rigid Neogene formations, show very low deformation rates, ranging between -1.5 and $1.5 \mathrm{~mm} / \mathrm{yr}$ (close to the technique's sensitivity), indicating relatively stable ground conditions. Nevertheless, PSI results show that subsidence was widespread throughout the western suburbs of the Thessaloniki metropolitan area, in the period from 1995 to 2001. In particular, intense land subsidence can be clearly identified in the coastal area of Kalochori and south of Sindos. There, the highest LOS velocities ranged between 15 and $30 \mathrm{~mm} / \mathrm{yr}$ in 1995-2001, with peak values of $40 \mathrm{~mm} / \mathrm{yr}$. The recorded phenomena can be attributed to the groundwater extraction, which causes compaction of the fine-grained deposits of the aquifer systems. These welldefined deformation areas are truncated along a NW-SE oriented alignment. In particular, northeast of Kalochori, LOS deformation rates decrease rapidly, down to zero within few kilometers. The lack of subsidence in these areas indicates that both significant thicknesses of compressible sediments are missing and water level has not declined sufficiently to cause compaction of the sediments.

More than 1000 point-wise measurements points have been yielded for the $10 \mathrm{~km}^{2}$ wide-Kalochori region. Almost 500 PS have been identified in the urban fabric of Sindos. Such density of points ensures an almost spatially continuous coverage of information on surface deformation and related hazards. This makes InSAR ideally suited to map the extension of threatened areas, improving confidence on spatial pattern of the examined phenomenon. A further benefit of PSI techniques is the generation of time series of the relative LOS position for each PS target in correspondence of each SAR acquisition, allowing analysis of temporal evolution of displacement and calculation of cumulated displacement for the investigated period of time (Fig. 5).

\subsection{Comparison of PS velocities with thickness of compressible deposits}

Compaction of the aquifer system depends not only on piezometric level variations, but also on the geometrical and geotechnical characteristics of the aquifer deposits, namely thickness and compressibility. Variability of both water head level and thickness of compressible fine-grained deposits contributes to the different deformation patterns observed in the Sindos-Kalochori area.

According to the findings of geoelectrical investigation (Nikolaou and Nicolaidis, 1987) and on drill profile data from an oil drilling investigation program, conducted in 1963 (Demiris, 1988), the loose Quaternary deposits reach a maximum depth of $400 \mathrm{~m}$, with the highest values observed close to the coastline (Fig. 4). Their thickness decreases to the NE of the study area, where finally the underlay Neogene formations outcrop on the surface.

Taking into account the above-described variations on the thickness of the Quaternary deposits, the correlation between greater subsidence values and thickness of the compressible sediments throughout the whole urban area is clear (Fig. 4).

Indeed, along the shoreline, where compressible sediments gain considerable thickness, ground deformation increases severely; moving north and north-east of the villages, the intense gradient in subsidence decrease is clearly related to the thinning of alluvial deposits. 


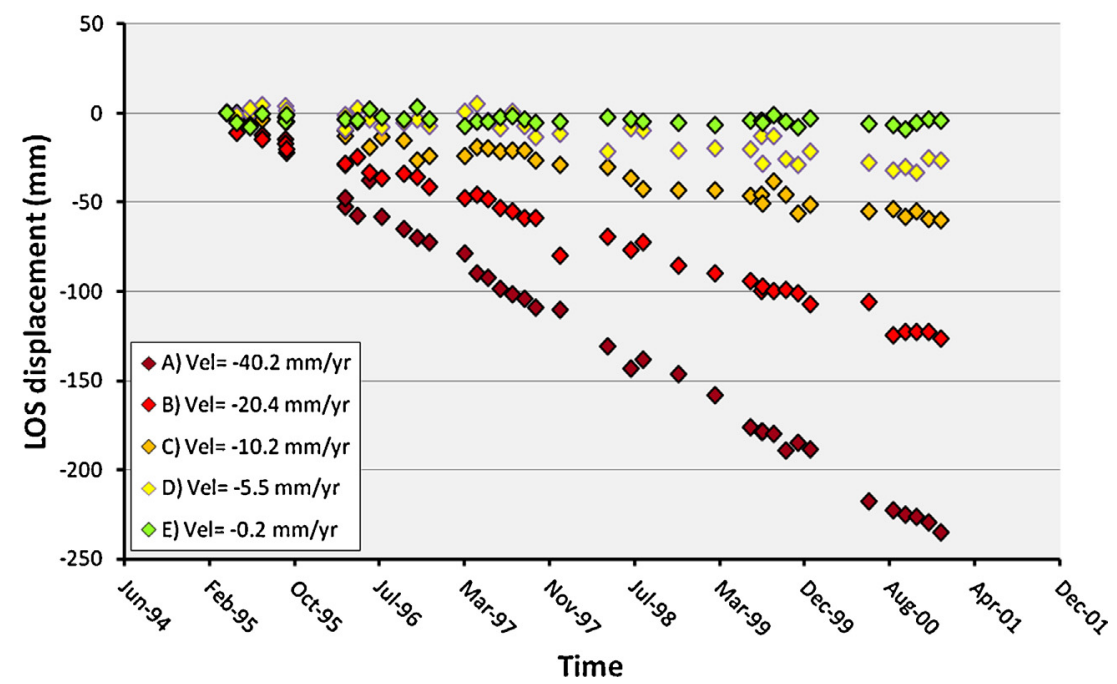

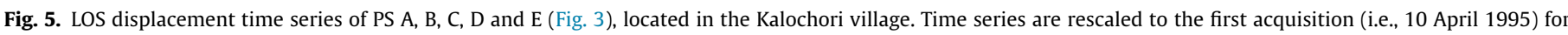
visualization purpose only.

A thickness map of compressible strata was elaborated by Nikolaou and Nicolaidis (1987), through geo-electrical investigations (curves in Fig. 4). This map allows analyzing the relationship between the point-wise information on land subsidence and the cumulative thickness of compressible deposits (i.e., Quaternary sediments). A quantitative comparison between subsidence and thickness of the compressible sediments has been performed (Fig. 6).

The spatially continued information on compressible thickness (considering both the shallow and the deeper deposits) has been divided into several classes, using an increment pass
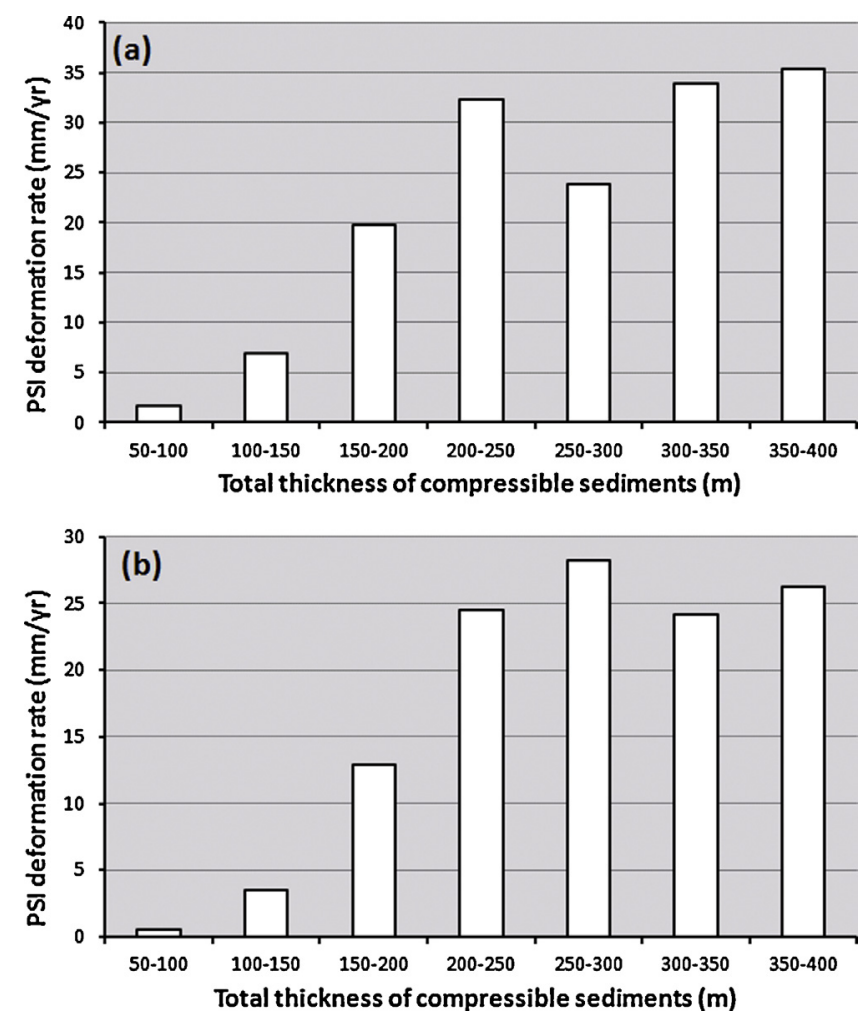

Fig. 6. Comparison of PSI-based subsidence estimates with the total thickness of Quaternary compressible sediments retrieved by the geoelectrical profiles in Sindos (a) and Kalochori (b) area. of $50 \mathrm{~m}$. The arithmetic mean of the velocities of all the PSs located within the different thickness classes has been calculated. The bars of histogram, representing the average PSI deformation rate found in each of these classes, were drawn. For both Sindos and Kalochori area it is observed that the thicker the cumulate compressible deposits the higher the subsidence rates.

\subsection{Comparison of PS time series with leveling benchmarks}

The accuracy of the PSI measurements is often difficult to assess when comparable ground-based measurements are not available. In the Kalochori wider area, Doukas et al. (2004) established in 1992 a high precision leveling control network in order to monitor subsidence phenomena. Over a territory $12 \mathrm{~km}^{2}$ wide, 37 stations (named R1, R2, R3, .., R37), were installed in cooperation with the public service of water supply of Thessaloniki. The network was measured several times in a period of twelve years, carrying out 10 leveling campaigns.

Within the current study, the PSI accuracy has been assessed by comparing SAR-retrieved deformations with those from leveling instrumentation. The main idea is to compare qualitatively the measurements available from the leveling benchmarks with the vertical component of the displacement retrieved at nearby PS with interferometric analysis. The evaluation of the leveling measurements shows that the greatest subsidence has occurred in the South-West area of Kalochori (i.e., control point R28 of the leveling network) with a mean subsidence velocity of roughly $4.6 \mathrm{~cm} /$ year. From April 1995 to January 2001 a cumulative subsidence of $250 \mathrm{~mm}$ was recorded (Doukas et al., 2004). In the same period, a cumulated displacement of $240 \mathrm{~mm}$ (mean deformation rate of $4.2 \mathrm{~mm} / \mathrm{yr}$ ) was detected in the same area by means of PSI technique. Results of comparison activities performed for four leveling benchmarks selected in the area of the village of Kalochori are summarized in Fig. 7.

\section{Subsidence simulation and validation through PSI}

\subsection{Model implementation}

The first step of the model configuration consists in the creation of realistic and at the same time simplified geological profiles, representative of the investigated area. Other crucial input parameters 

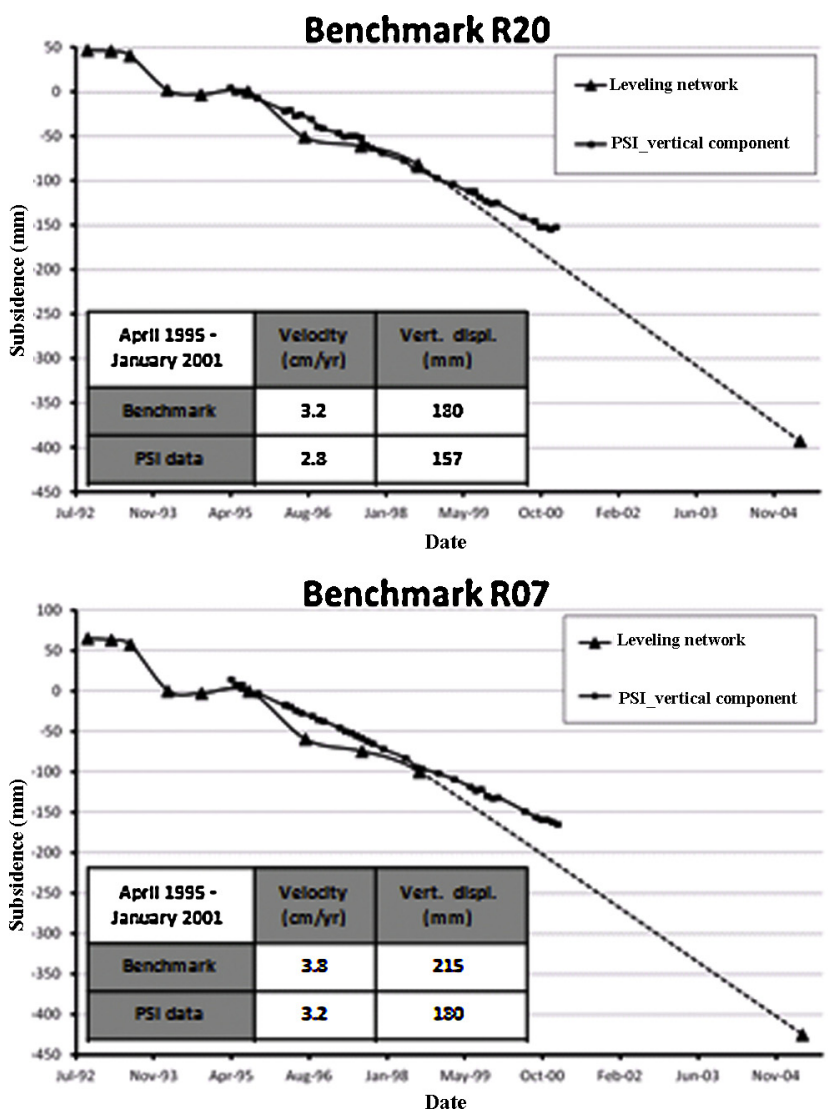

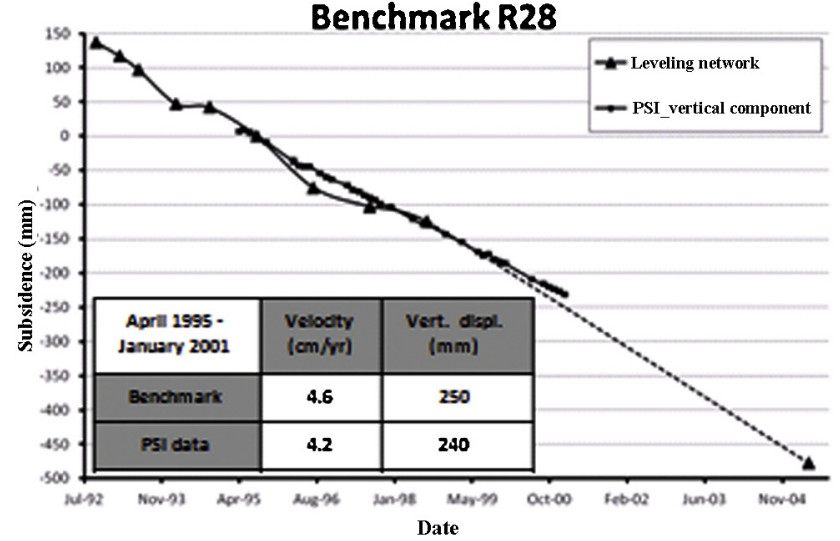

Benchmark R02

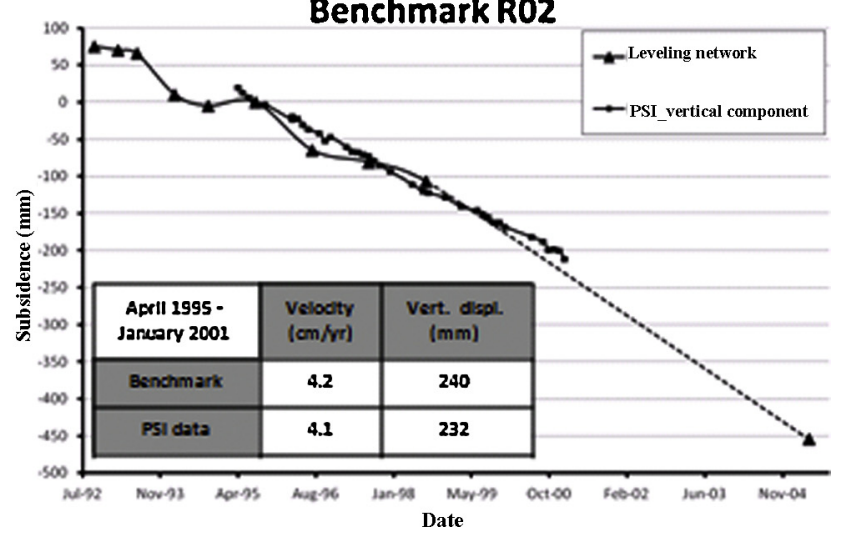

Fig. 7. Comparison between the vertical component of PSI measures and leveling data at benchmark R20, R28, R07 and R02. Location of benchmarks is shown in Fig. 3 .

necessary for the configuration of this model are the geotechnical properties of the various soil layers as well as the groundwater fluctuations history. By obtaining this data the constitutive laws reproducing the stress-strain relationship of the materials as well as the loading history of the materials can be appointed, simulating the phenomenon.

The plenty of stratigraphic, geotechnical and the hydrogeological data available for the wider Kalochori village region, including many hydrogeological drills and a significant number of deep geotechnical drills, penetrating the alluvial deposits down to the depth of $90 \mathrm{~m}$, were interpreted and correlated to construct simplified two-dimensional geological profiles of this sector of the Thessaloniki plain.

The simulation procedure was applied in two representative profiles ( $100 \mathrm{~m}$ and $150 \mathrm{~m}$ thick). The thickness of the profiles was selected taking into account the depth of the deepest productive wells exploiting the deep confined aquifers (about $150 \mathrm{~m}$ ), by considering the depth of the available information on the loose Quaternary deposits (100-150 m) and the water level variations (more than $30 \mathrm{~m}$ of drawdown in 1955-1995). The pattern and the thickness of the geological formations are clearly presented in Fig. 8 and they are identical in both profiles. The only difference is that in the $100 \mathrm{~m}$ deep profile the bottom layers are missing. This simulation was conducted by using the PLAXIS two-dimensional finite element code (Brinkgreve et al., 2002). The application of a two-dimensional code can be considered sufficient as the present study practically deals with the simulation of a typical cross section with no horizontal transitions.

Setting up the simulation profile, a close consolidation boundary was applied at the base and at the sides of the profiles for the configuration of the excess pore pressure along the boundaries. Standard horizontal and vertical fixities were applied and the coarseness of the mesh was selected to be fine in order to fit the narrow geological layers.

When dealing with geotechnical modeling, the identification of the appropriate criterion underpinning the model itself is the fundamental starting point. In the current study, the Mohr-Coulomb elastic-perfectly plastic model was considered to be the appropriate constitutive law for the simulation of the geomaterials. In addition, calculations have been carried out by using the consolidation theory.

The final values of the mechanical parameters selected for the simulation of the geological formations are presented in Table 2. Spatial variability of the physical and mechanical parameters was also estimated to develop the proper geotechnical model and to characterize each discretized layer.

Most of the geological and geotechnical information on the soil layers came out from the re-evaluation of the old laboratory tests conducted by Andronopoulos (1979) and Andronopoulos et al. (1990).

Most of the required values of the geotechnical properties have been obtained from oedometer tests, widely used in experimental soil mechanics to reproduce the one-dimensional consolidation and drainage conditions that soils experience in the field as a response to a change in effective stress. Being developed at the beginning of 19th century, oedometer test is one of the most consolidated and well-established geotechnical investigations and is performed simply by applying different loads to a soil sample and measuring the deformation response. Hence, available geotechnical data and parameters deriving from oedometer test can be considered robust and reliable despite their different sources and age. For instance, some of the re-evaluated geotechnical tests, considered to be accurate, have been performed in the 1970 s. 


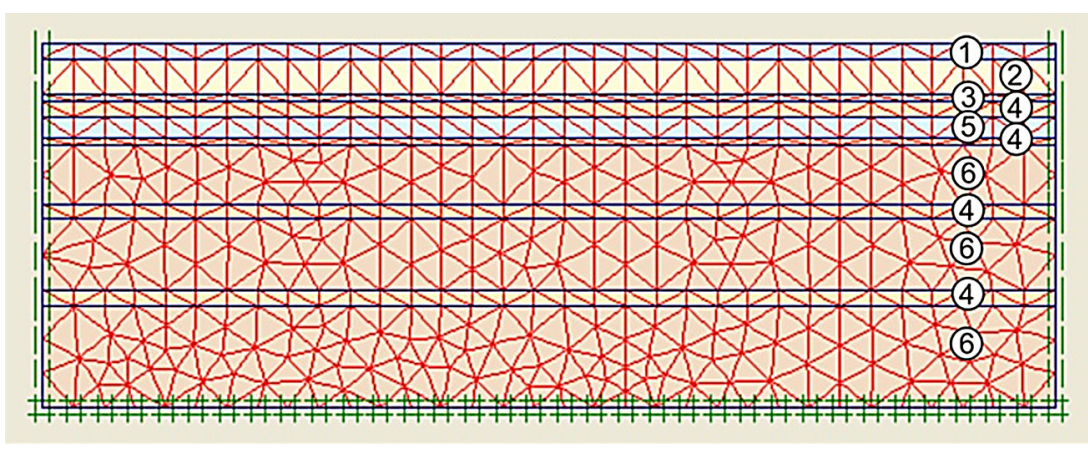

Fig. 8. The simulation profile. Soil layers are indicated in respect to their reference at Table 2.

Table 2

Soil data sets parameters coming from the re-evaluation of the available laboratory and in situ tests as indicated in the cross section of Fig. 8 .

\begin{tabular}{|c|c|c|c|c|c|c|}
\hline & $\begin{array}{l}\text { [1] Yellow-brown } \\
\text { sand }\end{array}$ & $\begin{array}{l}\text { [2] Gray silty } \\
\text { sand }\end{array}$ & $\begin{array}{l}\text { [3] Brown sand } \\
\text { silty sand }\end{array}$ & $\begin{array}{l}\text { [4] Black-gray } \\
\text { silty sand II }\end{array}$ & $\begin{array}{l}\text { [5] Brown sand } \\
\text { silty sand II }\end{array}$ & $\begin{array}{l}\text { [6] Brown sand } \\
\text { silty sand III }\end{array}$ \\
\hline Draining conditions & Drained & Drained & Drained & Drained & Drained & Drained \\
\hline$\gamma$ unsat $\left(\mathrm{kN} / \mathrm{m}^{3}\right)$ & 1900 & 17.40 & 19.50 & 17.50 & 18.50 & 19.50 \\
\hline$\gamma \operatorname{sat}\left(\mathrm{kN} / \mathrm{m}^{3}\right)$ & 20.00 & 18.00 & 22.00 & 19.80 & 20.60 & 22.00 \\
\hline$k x, k y(\mathrm{~m} /$ day $)$ & 8.928 & 0.638 & 8.928 & 0.638 & 8.928 & 8.928 \\
\hline Eoed $\left(\mathrm{kN} / \mathrm{m}^{2}\right)$ & 3950 & 3100 & 11600 & 8800 & 15000 & 20000 \\
\hline $\operatorname{cref}\left(\mathrm{kN} / \mathrm{m}^{2}\right)$ & 10 & 60 & 35 & 80 & 10 & 40 \\
\hline$\varphi\left({ }^{\circ}\right)$ & 38.5 & 7 & 40 & 15 & 38.5 & 40 \\
\hline$\varphi\left({ }^{\circ}\right)$ & 3 & 0 & 5 & 0 & 3 & 5 \\
\hline $\operatorname{Einc}\left(\mathrm{kN} / \mathrm{m}^{2} / \mathrm{m}\right)$ & - & - & - & 360 & - & - \\
\hline $\operatorname{yref}(\mathrm{m})$ & - & - & - & 40 & - & - \\
\hline
\end{tabular}

Besides the geotechnical behavior of the soil, the water table variations were also used as input parameters for the simulation model. Forty-one wells have been analyzed to retrieve information on piezometric level changes in the shallow and deep aquifers in the area of interest.

As mentioned in the hydrogeological settings paragraph, the piezometric level in the majority of the deep wells drilled in Kalochori region in 1955 was above the ground surface. Therefore, initial piezometric surface of the confined aquifers was set $5 \mathrm{~m}$ above the ground surface. In order to simulate the lowering of the water table the simulation procedure was divided in four calculation phases, according to the different phases of confined aquifers exploitation. During the first three phases the piezometric level was reduced from $+5 \mathrm{~m}$ to $-27 \mathrm{~m}$, according to the progressive drawdown occurred between early 1960 and 1995. During the last phase the level was reduced for an extra -1 to $-3 \mathrm{~m}$, simulating the limited variations recorded between 1997 and 2001 (Fig. 2). On the contrary, the water table level of the unconfined shallow aquifer was set $5 \mathrm{~m}$ below the ground surface and it was kept stable during the entire calculation procedure, since it has never been exploited.

In order to isolate the land deformations caused by the 1997-2001 extra drawdown and compare them with the PSI data, the displacements were "reset to zero" at the beginning of the last calculation phase.

The calculations were carried out using the "consolidation analysis" procedure, a typical analysis defined by the selected calculation model. The gradual reduction of the piezometric surface was applied by means of the "stage construction" routine. Prior to the four calculation phases mentioned above, "Ko procedure" was applied in order to configure the initial stress fields.

\subsection{Model results and validation}

The results obtained from the simulation are summarized for both geological profiles and for all three possible piezometric surface downgrading scenarios in Table 3. The displacements calculated by applying the Mohr-Coulomb model at the simplified geological profile of the site fit greatly the deformation recorded by PSI data. For the validation, the PS points in the area of the Kalochori village (corresponding to the area of the geotechnical model) have been selected and corresponding time series of deformation have been analyzed to retrieve a minimum, mean and maximum value of vertical displacement. In particular, Tables 3 and 4 demonstrate the similarity between the deformations computed simulating drawdown and those measured by PSI analysis. For the period of time (1995-2001), introduced within the simulation as a -1 to $-2 \mathrm{~m}$ extra ground water drawdown, simulations indicate deformations ranging from 10.4 to $27.4 \mathrm{~cm}$ (Table 3 ) and PSI data (Table 4) recorded deformation from 9.8 to $26.2 \mathrm{~cm}$.

Furthermore, considering the cumulative vertical displacements since the $1960 \mathrm{~s}$, the simulation results presented a maximum value of $4.16 \mathrm{~m}$, coinciding perfectly with the qualitative estimation of the maximum total vertical deformations along the embankments, mentioned in paragraph 2.2 (Fig. 3).

The simulations presented that the soil layer with the biggest contribution to the total vertical displacements is the black-gray silty sand extending from 10 to $35 \mathrm{~m}$ in depth, operating as the boundary formation between the deep confined and the shallow

Table 3

Simulated vertical displacement for different decrease of piezometric level.

\begin{tabular}{lcc}
\hline Vert. disp. $(\mathrm{cm})$ & 100 m deep profile & 150 m deep profile \\
\hline-5 to -27 m drawdown & 283 & 376 \\
1 m extra drawdown & 10.4 & 15.6 \\
2 m extra drawdown & 20.5 & 27.4 \\
3 m extra drawdown & 30.7 & 40.3 \\
\hline
\end{tabular}

Table 4

Summary of PSI vertical cumulate displacement for the Kalochori area.

\begin{tabular}{lr}
\hline PSI data vert. disp. (in cm) 1995-2001 \\
\hline Minimum value & 9.8 \\
Mean value & 17.8 \\
Peak displacement & 26.2
\end{tabular}




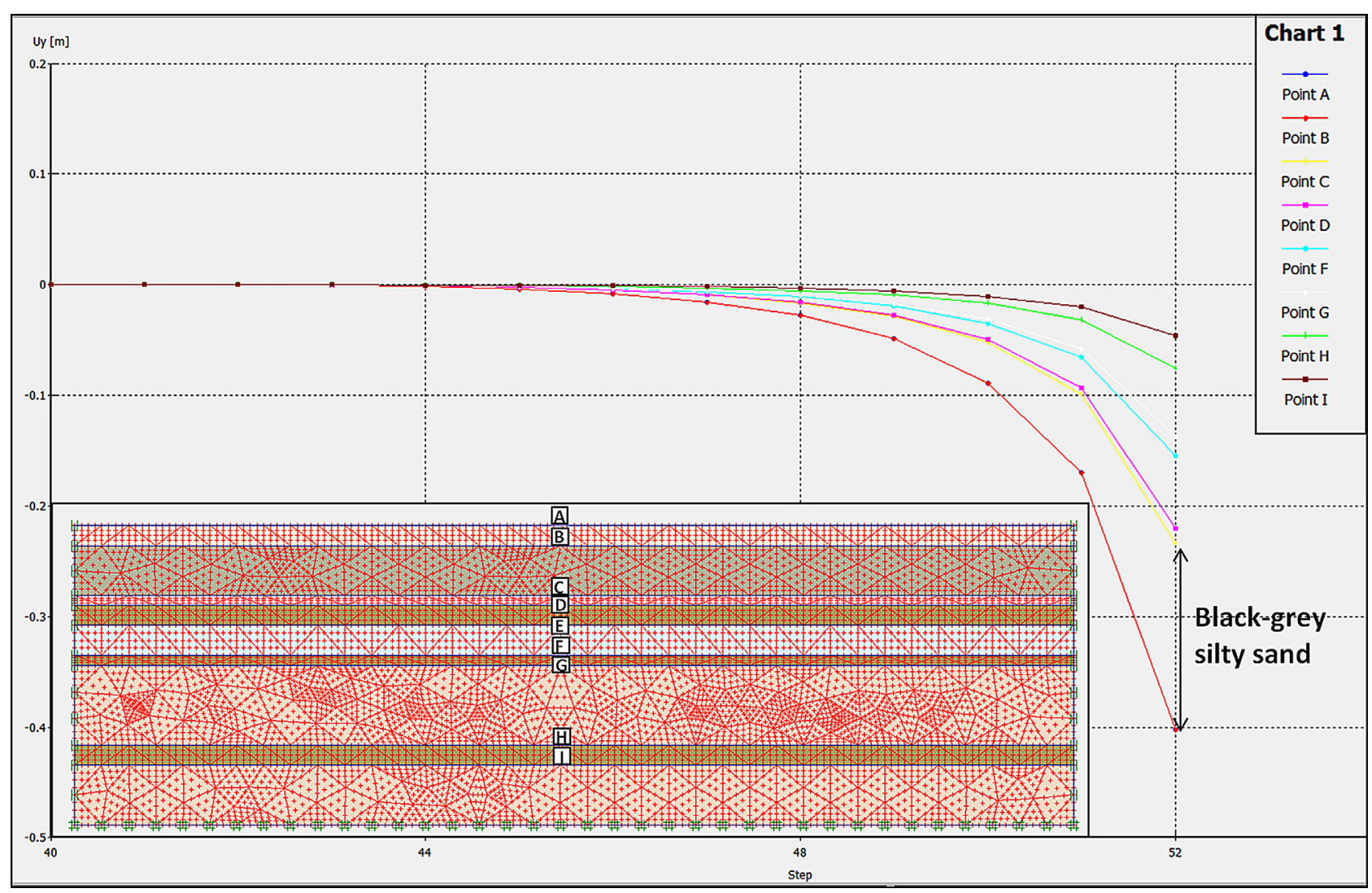

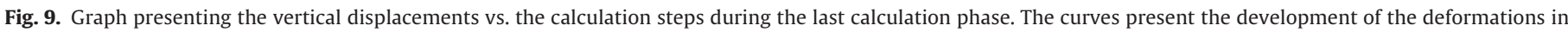
critical points selected at the bases of the layers forming the $150 \mathrm{~m}$ deep profile. Nodes A-I are shown in the inset.

unconfined aquifers. This fact is clearly presented in the graphs of Fig. 9 and it is justified by the low oedometer stiffness modulus of the particular formation (Table 2 ).

\section{Discussion}

The main purpose of the WAP approach over Greece was to process and mosaic several adjacent satellite image frames to produce a PSI ground motion map covering approximately half of the country's territory and offering a synoptic view of the geo-hazard related deformations, such as those caused by active tectonics or hydro-geological hazards. This map was created using 10 individual ERS-1/2 stacks, each stack being a time series of 58-76 SAR images acquired from 1992 to 2002 for a total of 671 images. WAP identified over a million persistent scatterers over an area of about $65000 \mathrm{~km}^{2}$. This amount of information has been exploited to identify specific areas of deformation, corresponding to sites affected by geo-hazards, within wider regions of interest. Among the numerous sites in Greece affected by geo-hazards, the Delta municipality was selected due to its long history of land subsidence and furthermore because a general agreement on the generation mechanism of the subsidence is still missing.

The results, obtained by the modeling, indicate that the occurred excessive deformations in the wider Kalochori region can be attributed to the overexploitation of the confined aquifer, contributing to the identification of the main triggering factor of subsidence in this area.

The evaluation of the available geotechnical data as well as the parametric analyses conducted by using the PSI data proved that the elastic-perfectly plastic model based on the Mohr-Coulomb failure criterion (Mohr-Coulomb model) can be considered appropriate for the direct simulation of the land subsidence. In most of the cases land subsidence phenomena cannot be back calculated, because of the lack of accurate records of historical displacement and, therefore, the implementation of a verified simulation procedure cannot be established. In those cases, the knowledge that the Mohr-Coulomb soil model (a simple model with low requirements on mechanical parameters) can provide accurate results can be considered highly valuable.

The procedure presented in this study, can be also used to calculate and to assess the effect of an extra piezometric drawdown, predicting aquifer responses to various water-management alternatives and evaluating the effect on the ground elevation of a hypothetic new overexploitation of the aquifer. The validated simulation procedure represents a useful tool for scientific communities, decision makers and local administrator. A complete subsidence mapping, coupled with the knowledge of the underpinning mechanism, represents a fundamental parameter for adequate planning and design of mitigation works, which should be realized for a better hazards management and for risk mitigation.

Considering the progressive recovery of the semi-confined aquifers piezometric level during the last 10 years (2002-2012), the subsidence rates is supposed to have declined accordingly. Unfortunately, the lack of PSI data showing the recent (post 2001) and current pattern of deformation does not allow any further estimation about the evolution of the attenuating subsidence phenomenon in the Kalochori area.

It is worth remember that land deformations are not expected to nullify accordingly to the rising ground-water levels. The occurrence of a thick aquitards, separating the shallow unconfined and the deep confined aquifer systems at the Kalochori site, might have generated a residual compaction which, in turn, results in a delayed subsidence, occurring long after the heads in the aquifers have ceased declining or have recovered significantly. 
Indeed, as reported by many authors (Bell et al., 2008; Hoffmann et al., 2001; Ireland et al., 1984), the presence of slowly equilibrating aquitards can generate lag in the dissipation of residual excess pore water pressure, introducing a major time delay between changes in hydraulic head of the aquifers and the deformation in the aquitards. This factor represents an important issue to consider in the long-term management of water resources and in assessing the effectiveness of mitigation programs, as deformations cannot be stopped rapidly by just stopping the overexploitation of the aquifers.

\section{Conclusions}

The WAP-derived information on displacement, gathered processing a set of forty-two ERS1/2 SAR images, contributed to identify and map subsiding zones and rates of deformation in the urbanized areas of Sindos and Kalochori in 1995-2001. For this sector of the Thessaloniki plain, WAP data revealed a main pattern of subsidence corresponding to intense groundwater withdrawal. Highest displacement velocities (up to $4.5 \mathrm{~cm} / \mathrm{year}$ ) have been observed south-west of Kalochori and south of Sindos, where maximum thickness of compressible Quaternary sediments occurs.

Besides the analysis of PSI data to retrieve information on deformation rate and extent of subsidence already occurred, the purpose of this work was to develop and validate a model to examine the land subsidence by means of a finite element simulation analysis.

A two-dimensional finite element simulation was carried out along two representative profiles in the Kalochori area, coupling recorded variations of the water table and geotechnical behavior of the subsoil. Positive correlation between the computed deformations and the measurement of past displacements retrieved by PSI analyses validates the results of the simulation in the best possible way. This demonstrated that the excessive total vertical deformations, exceeding $4 \mathrm{~m}$, estimated by means of the modeling activity could be attributed unambiguously to the groundwater overexploitation, which caused compaction of the fine-grained deposits of the aquifer. Moreover, the performed parametric analyses proved that the elastic-perfect plastic model based on the Mohr-Coulomb failure criterion is an appropriate model for the simulation of land subsidence phenomena.

Finally, SAR satellite observations demonstrated their potential and suitability as alternative, cost-efficiency method for the management of subsidence-related hazards and turned out to be a valuable tool to verify and validate subsidence models.

\section{Acknowledgments}

The Terrafirma Extension project (http://www.terrafirma. eu.com/index.htm) has funded the SAR imagery processing as well as the geotechnical modeling presented in this paper. The project is one of ten services being supported by the Global Monitoring for Environment and Security (GMES) Service Element Program, promoted and financed by the European Space Agency (ESA). The authors wish to thank the editor and the two reviewers for their valuable comments and suggestions.

\section{References}

Adam, N., Rodriguez Gonzalez, F., Parizzi, A., Brcic, R., 2013. Wide area persistent scatterer interferometry: current developments, algorithms and examples. In: Proceedings of IGARSS 2013, Melbourne, Australia.

Adam, N., Rodriguez Gonzalez, F., Parizzi, A., Liebhart, W., 2011. Wide area persistent scatterer interferometry. In: Proceedings of IGARSS 2011, Vancouver, Canada, pp. 1481-1484.

Amelung, F., Galloway, D.L., Bell, J.W., Zebker, H.A., Laczniak, R.L., 1999. Sensing the ups and downs of Las Vegas: InSAR reveals structural control of land subsidence and aquifer-system deformation. Geology 27 (6), 483-486.
Amelung, F., Jónsson, S., Zebker, H., Segall, P., 2000. Widespread uplift and 'trapdoor' faulting on Galápagos volcanoes observed with radar interferometry. Nature 407, 993-996.

Andronopoulos, B., 1979. Geological and Geotechnical Study in the Kalohori (Thessaloniki) Area. Engineering Geology Investigations, vol. 10. IGME, Athens.

Andronopoulos, B., Rozos, D., Hatzinakos, I., 1990. Geotechnical Study of the Subsidence Phenomena in Kalohori Area. IGME, Unpublished Report.

Andronopoulos, V., Rozos, D., Hatzinakos, I., 1991. Subsidence phenomena in the industrial area of Thessaloniki Greece. In: Johnson, A. (Ed.), Land Subsidence, vol. 200. IAHS Publishers, pp. 59-69.

Arnaud, A., Adam, N., Hanssen, R., Inglada, J., Duro, J., Closa, J., Eineder, M., 2003. ASAR ERS interferometric phase continuity. In: Proceedings of IGARSS 2003, France, Toulouse.

Bell, J.W., Amelung, F.A., Ferretti, A., Bianchi, M., Novali, F., 2008. Permanent scattere InSAR reveals seasonal and long-term aquifer-system response to groundwater pumping and artificial recharge. Water Resources Research 44 (2), 2407-2425.

Berardino, P., Fornaro, G., Lanari, R., Sansosti, E., 2002. A new algorithm for surface deformation monitoring based on small baseline differential SAR interferograms. IEEE Transaction on Geoscience and Remote Sensing 40 (11), 2375-2383.

Bianchini, S., Cigna, F., Righini, G., Proietti, C., Casagli, N., 2012. Landslide HotSpot mapping by means of persistent scatterer interferometry. Environmental Earth Sciences 67 (4), 1155-1172.

Bovenga, F., Wasowski, J., Nitti, D.O., Nutricato, R., Chiaradia, M.T., 2012. Using COSMO/SkyMed X-band and ENVISAT C-band SAR interferometry for landslides analysis. Remote Sensing of Environment 119, 272-285.

Brinkgreve, R.B.J., Al-Khoury, R., Bakker, K.J., 2002. Plaxis, Fine Element Code for Soil and Rock Analysis, 2D. Version 8. Balkema, Rotterdam.

Brunori, C.A., Bignami, C., Stramondo, S., Bustos, E., 2013. 20 years of active deformation on volcano caldera: joint analysis of InSAR and AInSAR techniques. International Journal of Applied Earth Observation and Geoinformation 23 279-287.

Bürgmann, R., Hilley, G.E., Ferretti, A., 2006. Resolving vertical tectonics in the San Francisco Bay area from permanent scatterer InSAR and GPS analysis. Geology 34, 221-224.

Cakir, Z., Chabalier, J.B., Armijo, R., Meyer, B., Barka, A., Peltzer, G., 2003. Coseismic and early post-seismic slip associated with the 1999 Izmit earthquake (Turkey) from SAR interferometry and tectonic field observations. Geophysical Journal International 155 (1), 93-110.

Chaussard, E., Amelung, F., Abidin, H., Hong, S.H., 2013. Sinking cities in Indonesia: ALOS PALSAR detects rapid subsidence due to groundwater and gas extraction. Remote Sensing of Environment 128, 150-161.

Cigna, F., Bianchini, S., Casagli, N., 2012b. How to assess landslide activity and intensity with Persistent Scatterer Interferometry (PSI): the PSI-based matrix approach. Landslides, 1-17.

Cigna, F., Del Ventisette, C., Liguori, V., Casagli, N., 2011. Advanced radarinterpretation of InSAR time series for mapping and characterization of geological processes. Natural Hazards and Earth System Sciences 11 (3), 865-881.

Cigna, F., Osmanoğlu, B., Cabral-Cano, E., Dixon, T.H., Ávila-Olivera, J.A., GarduñoMonroy, V.H., Demets, C., Wdowinski, S., 2012a. Monitoring land subsidence and its induced geological hazard with Synthetic Aperture Radar Interferometry: a case study in Morelia, Mexico. Remote Sensing of Environment 117, 146-161.

Colesanti, C., Ferretti, A., Prati, C., Rocca, F., 2003. Monitoring landslides and tectonic motion with the Permanent Scatterers technique. Engineering Geology 68 (1-2), $3-14$.

Colesanti, C., Wasowski, J., 2006. Investigating landslides with space-borne Synthetic Aperture Radar (SAR) interferometry. Engineering Geology 88 (3-4), 173-199.

Costantini, M., Falco, S., Malvarosa, F., Minati, F.A., 2008. New method for identification and analysis of persistent scatterers in series of SAR images. In: Proceedings of IEEE International Geoscience and Remote Sensing Symposium, Boston, MA USA, pp. 449-452.

Demiris, K.,1988. Geological settings and their influence on the development of the areas on the west of Thessaloniki. In: Proceedings of the Symposium on the Technical Problems Affecting the Areas on the West of Thessaloniki. Technica Chamber of Greece, Thessaloniki.

Dimopoulos, G., 2005. Investigation of the conditions generating soil settlements in Sindos-Kalochori area of Thessaloniki. In: Proceedings of the 7th Hellenic Hydrogeological Conference and 2nd MEM Workshop on Fissured Rocks Hydrogeology, Athens. Hellenic Committee of Hydrogeology, pp. 135-146.

Dixon, T.H., Amelung, F., Ferretti, A., Novali, F., Rocca, F., Dokka, R., Sella, G., Kim, S.W., Wdowinski, S., Whitman, D., 2006. Subsidence and flooding in New Orleans - a subsidence map of the city offers insight into the failure of the levees during Hurricane Katrina. Nature 441, 587-588.

Doukakis, E.,2005. Coastal red spots along the western Thermaikos gulf. In: Proceedings of the 9th International Conference on Environmental Science and Technology. University of Aegean, Rhodes, Greece, pp. A334-A339.

Doukas, I.D., Ifadis, I.M., Savvaidis, P., 2004. Monitoring and analysis of ground subsidence due to water pumping. In: FIG Working Week, Athens, Greece, May $22-27$.

Duro, J., Closa, J., Biescas, E., Crosetto, M., Arnaud, A., 2005. High resolution differential interferometry using time series of ERS and ENVISAT SAR data. In Proceedings of the 6th Geomatic week conference, Barcelona, Spain, 8-11 February.

Farina, P., Colombo, D., Fumagalli, A., Marks, F., Moretti, S., 2006. Permanent Scatterers for landslide investigations: outcomes from the ESA-SLAM project. Engineering Geology 88, 200-217. 
Ferretti, A., Fumagalli, A., Novali, F., Prati, C., Rocca, F., Rucci, A., 2011. A new algorithm for processing interferometric data-stacks: SqueeSAR ${ }^{\mathrm{TM}}$. IEEE Transactions on Geoscience and Remote Sensing 99, 1-11.

Ferretti, A., Prati, C., Rocca, F., 2000. Nonlinear subsidence rate estimation using Permanent Scatterers in differential SAR interferometry. IEEE Transactions on Geoscience and Remote Sensing 38 (5), 2202-2212.

Ferretti, A., Prati, C., Rocca, F., 2001. Permanent Scatterers in SAR interferometry. IEEE Transactions on Geoscience and Remote Sensing 39 (1), 8-20.

Gabriel, A.K., Goldstein, R.M., Zebker, H.A., 1989. Mapping small elevation changes over large areas: differential radar interferometry. Journal of Geophysical Research 94, 9183-9191.

Galloway, D.L., Burbey, T.J., 2011. Review: regional land subsidence accompanying groundwater extraction. Hydrogeology Journal 19, 1459-1486.

Galloway, D.L., Hudnut, K.W., Ingebritsen, S.E., Phillips, S.P., Peltzer, G., Rogez, F., Rosen, P.A., 1998. Detection of aquifer system compaction and land subsidence using interferometric synthetic aperture radar, Antelope Valley, Mojave Desert, California. Water Resources Research 34 (10), 2573-2585.

Gambolati, G., Teatini, P., Ferronato, M., 2005. Anthropogenic land subsidence. In: Anderson, M.G.(Ed.), Encyclopedia of Hydrological Sciences. Wiley, Wiley Online Library, $17 \mathrm{pp}$.

Hatzinakos, I., Rozos, D., Apostolidis, E., 1990. Engineering geological mapping and related geotechnical problems in the wider industrial area of Thessaloniki, Greece. In: Price, D. (Ed.), Proceedings of Sixth International IAEG Congress. Balkema, Amsterdam, Netherlands, pp. 127-134.

Hayashia, T., Tokunaga, T., Aichi, M., Shimada, J., Taniguchi, M., 2009. Effects of human activities and urbanization on groundwater environments: an example from the aquifer system of Tokyo and the surrounding area. Sciences of Total Environment 407, 3165-3172.

Herrera, G., Fernandez, J.A., Tomas, R., Cooksley, G., Mulas, J., 2009. Advanced interpretation of subsidence in Murcia (SE Spain) using A-DInSAR datamodelling and validation. Natural Hazards Earth System Science 9 647-661.

Herrera, G., Gutiérrez, F., García-Davalillo, J.C., Notti, D., Galve, J.P., FernándezMerodo, J.A., Cooksley, G., 2013. Multi-sensor advanced DInSAR monitoring of very slow landslides: the Tena valley case study (central Spanish Pyrenees) Remote Sensing of Environment 128, 31-43.

Hoffmann, J., Zebker, H.A., Galloway, D.L., Amelung, F., 2001. Seasonal subsidence and rebound in Las Vegas Valley, Nevada, observed by synthetic aperture radar interferometry. Water Resources Research 37 (6), 1551-1566.

Hooper, A., Segall, P., Zebker, H.A., 2007. Persistent scatterer interferometric synthetic aperture radar for crustal deformation analysis, with application to Volcán Alcedo, Galápagos. Journal of Geophysical Research 112

Hooper, A., Zebker, H.A., Segall, P., Kampes, B., 2004. A new method for measuring deformation on volcanoes and other natural terrains using InSAR persisten scatterers. Geophysical Research Letters 31

Hung, W.C., Hwang, C., Chang, C.P., Yen, J.Y., Liu, C.H., Yang, W.H., 2010. Monitoring severe aquifer-system compaction and land subsidence in Taiwan using multiple sensors: Yunlin, the southern Choushui River alluvial fan. Environmental Earth Sciences 59 (7), 1535-1548.

IGME - Institute of Geological and Mineralogical Exploration, 1978. Geological Map of Greece, Scale 1:50.000, Thessaloniki Sheets. IGME, Athens.

Ireland, R.L., Poland, J.F., Riley, F.S., 1984. Land subsidence in the San Joaquin Valley, California as of 1980. U.S. Geologial Survey, 437-I, 93 pp.

Kampes, B., Usai, S.,1999. Doris: the delft object-oriented radar interferometric software. In: Proceedings of the 2 nd International Symposium on Operationalization of Remote Sensing. Enschede, The Netherlands.

Ketelaar, V.B.H., 2009. Satellite Radar Interferometry: Subsidence Monitoring Techniques. Springer-Verlag, New York (Chapter 3).

Kontogianni, V., Pytharouli, S., Stiros, S., 2007. Ground subsidence, quaternary faults and vulnerability of utilities and transportation networks in Thessaly, Greece. Environmental Geology 52, 1085-1095.

Lanari, R., Mora, O., Manunta, M., Mallorquì, J.J., Berardino, P., Sansosti, E., 2004. A small baseline approach for investigating deformation on full resolution differential SAR interferograms. IEEE Transaction on Geoscience and Remote Sensing 42 (7), 1377-1386

Liu, P., Li, Z.H., Hoey, T., Kincal, C., Zhang, J.F., Zeng, Q.M., Muller, J., 2013. Using advanced InSAR time series technique to monitor landslide movements in Badong of the three Gorges region, China. International Journal of Applied Earth Observation and Geoinformation 21, 253-264.

Loupasakis, C., Rozos, D., 2009. Land subsidence induced by water pumping in Kalochori village (North Greece) - simulation of the phenomenon by means of the finite element method. Quarterly Journal of Engineering Geology and Hydrogeology 42 (3), 369-382.

Luo, Q., Perissin, D., Dogan, O., Lin, H., 2012. Tianjin suburbs PS-OPS analysis and validation with leveling data. In: Proceedings of IGARSS 2012, Munich Germany.

Massonnet, D., Feigl, K.L., 1995. Discrimination of geophysical phenomena in satellite radar interferograms. Geophysical Research Letters 22 (12) 1537-1540.

Massonnet, D., Feigl, K.L., 1998. Radar interferometry and its application to changes in the Earth's surface. Reviews of Geophysics 36 (4), 441-500.
Mora, O., Mallorquí,J.J., Broquetas, A., 2003. Linear and nonlinear terrain deformation maps from a reduced set of interferometric SAR images. IEEE Transactions on Geoscience and Remote Sensing 41, 2243-2253.

Mouratidis, A., Briole, P., Ilieva, M., Astaras, T., Rolandone, F., Baccouche, M., 2009. Subsidence and deformation phenomena in the vicinity of Thessaloniki ( $N$ Greece) monitored by Envisat/ASAR interferometry. In: Proceedings of Fringe 2009, Frascati, Italy.

Musson, R.M.W., Haynes, M., Ferretti, A., 2004. Space-based tectoning modelling in subduction areas using PSInSAR. Seismological Research Letters 75 (5), 598-606.

Ng, A.H.M., Ge, L., Li, X., Abidin, H.Z., Andreas, H., Zhang, K., 2012. Mapping land subsidence in Jakarta, Indonesia using persistent scatterer interferometry (PSI) technique with ALOS PALSAR. International Journal of Applied Earth Observation and Geoinformation 18, 232-242.

Nikolau, S., Nicolaidis, M., 1987. Geoelectric Study in Kalochori Village of Thessaloniki. Report. Institute of Geology and Mineral Exploration, Athens

Osmanoğlu, B., Dixon, T.H., Wdowinski, S., Cabral-Cano, E., Jiang, Y., 2011. Mexico City subsidence observed with persistent scatterer InSAR. Journal of Applied Earth Observation and Geoinformation 13 (1), 1-12.

Psimoulis, P., Ghilardi, M., Fouache, E., Stiros, S., 2007. Subsidence and evolution of the Thessaloniki plain, Greece, based on historical leveling and GPS data. Engineering Geology 90, 55-70.

Raspini, F., Cigna, F., Moretti, S., 2012. Multi-temporal mapping of land subsidence at basin scale exploiting Persistent Scatterer Interferometry: case study of Gioia Tauro plain (Italy). Journal of Maps 8 (4), 514-524.

Raspini, F., Loupasakis, C., Rozos, D., Moretti, S., 2013. Advanced interpretation of land subsidence by validating multi-interferometric SAR data: the case study of Anthemountas basin (Northern Greece). Natural Hazards and Earth System Sciences 13, 2425-2440.

Raspini, F., 2013. Landslide mapping using SqueeSAR data: the Giampilieri (Italy) case study. Rendiconti Online Societa Geologica Italiana 24, 263-265.

Raucoules, D., Parcharidis, I., Feurer, D., Novali, F., Ferretti, A., Carnec, C., Lagios, E., Sakkas, V., Le Mouelic, S., Cooksley, G., Hosford, S., 2008. Ground deformation detection of the greater area of Thessaloniki (Northern Greece) using radar interferometry techniques. Natural Hazards Earth System Sciences 8, 779-788.

Rozos, D., Apostolidis, E., Hatzinakos, I., 2004. Engineering-geological map of Thessaloniki wider area, Greece. Bulletin of Engineering Geology and the Environment 63, 103-108.

Rozos, D., Hatzinakos, I.,1993. Geological conditions and geomechanical behaviour of the neogene sediments in the area west of Thessaloniki (Greece). In: Proceedings of International Symposium on Geotechnical Engineering of Hard Soils-Soft Rocks. Balkema, Greece.

Rozos, D., Sideri, D., Loupasakis, C., Apostolidis, E., 2010. Land subsidence due to excessive ground water withdrawal: a case study from Stavros-Farsala site, West Thessaly, Greece. Proceedings of the 12th International Congress of the Geological Society of Greece 43 (4), 1850-1857.

Soulios, G., 1999. Research for the Development of the Aquifers in the Low Lands on the West of Thessaloniki for the Interests of the Water Company of Thessaloniki. Research Committee Technical Report. Aristotle University of Thessaloniki, pp. 99.

Stiros, S.C., 2001. Subsidence of the Thessaloniki (northern Greece) coastal plain, 1960-1999. Engineering Geology 61, 243-256.

Stramondo, S., Saroli, M., Tolomei, C., Moro, M., Doumaz, F., Pesci, A., Loddo, F., Baldi, P., Boschi, E., 2007. Surface movements in Bologna (Po Plain-Italy) detected by multitemporal DInSAR. Remote Sensing of Environment 110, 304-316.

Tofani, V., Raspini, F., Catani, F., Casagli, N., 2013. Persistent scatterer interferometry (PSI) technique for landslide characterization and monitoring. Remote Sensing 5 (3), 1045-1065

Tomás, R., Márquez, Y., Lopez-Sanchez, J.M., Delgado, J., Blanco, P., Mallorqui, J.J., Martinez, M., Herrera, G., Mulas, J., 2005. Mapping ground subsidence induced by aquifer overexploitation using advanced differential SAR Interferometry: Vega Media of the Segura River (SE Spain) case study. Remote Sensing of the Environment 98 (2-3), 269-283.

US National Research Council, 1991. Mitigating Losses From Land Subsidence in the United States. National Academy Press, Washington, DC.

van der Kooij, M., Hughes, W., Sato, S., Poncos, V., 2006. Coherent Target Monitoring at High Spatial Density: Examples of Validation Results. European Space Agency Spec. Publ., SP-610.

Werner, C., Wcgmuller, U., Strozzi, T., Wiesmann, A., 2003a. Interferometric point target analysis for deformation mapping. In: Proceedings of IGARSS 2003 Toulouse, Francia.

Werner, C., Wegmuller, U., Strozzi, T., Wiesmann, A., 2003b. Interferometric point target analysis with JERS L-band data. In: Proceedings of IGARSS 2003, Toulouse, Francia.

Xue, Y.Q., Zhang, Y., Ye, S.J., Wu, J.C., Li, O.F., 2005. Land subsidence in China. Environmental Geology 48 (6), 713-720.

Zebker, H.A., Villasenor, J., 1992. Decorrelation in interferometric radar echoes. IEEE Transactions on Geoscience and Remote Sensing 30, 950-959.

Zhang, Y., Zhang, J., Wu, H., Lu, Z., Guangtong, S., 2011. Monitoring of urban subsidence with SAR interferometric point target analysis: a case study in Suzhou, China. International Journal of Applied Earth Observation and Geoinformation $13,812-818$. 